\title{
IMPLEMENTASI MODEL PEMBELAJARAN KOOPERATIF TEAM ACCELERATED INSTRUCTION UNTUK MENINGKATKAN HASIL BELAJAR AKUNTANSI
}

\section{THE IMPLEMENTATION OF COOPERATIVE LEARNING METHOD TEAM ACCELERATED INSTRUCTION TO IMPROVE ACCOUNTING'S LEARNING OUTCOME}

\author{
Oleh: \\ Vilia Putri Sukmavahva \\ Prodi Pendidikan Akuntansi Universitas Negeri Yogyakarta \\ Viliaputri95@gmail.com \\ Diana Rahmawati \\ Staf Pengajar Jurusan Pendidikan Akuntansi Universitas Negeri Yogyakarta
}

\begin{abstract}
Abstrak
Penelitian ini bertujuan untuk meningkatkan Hasil Belajar Akuntansi Siswa kelas XI Akuntansi 4 SMK N 1 Jogonalan tahun ajaran 2016/2017 melalui Implementasi Model Pembelajaran Kooperatif Tipe Team Accelerated Instruction (TAI). Teknik pengumpulan data dengan tes, dan dokumentasi. Instrumen penelitian yang digunakan yaitu tes dan catatan lapangan.Teknik analisis data yang digunakan yaitu teknik analisis data deskitif kuantitatif. Berdasarkan hasil penelitian, pada siklus I nilai rata-rata Hasil Belajar Akuntansi pada pre test sebesar 44,33 meningkat menjadi sebesar 82,11 pada post test atau meningkat sebesar 37,78 atau $85,22 \%$. Pada siklus II, rata-rata Hasil Belajar Akuntansi pada pre test sebesar 48,89 meningkat menjadi sebesar 91,11 pada post test atau meningkat sebesar 42,22 atau 86,36\%. Ketuntasan Hasil Belajar Akuntansi pada pre test siklus I sebesar 5,56\% meningkat menjadi sebesar $63,89 \%$ pada post test atau meningkat sebesar $58,33 \%$. Pada siklus II, ketuntasan Hasil Belajar Akuntansi pada pre test sebesar 11,11\% meningkat menjadi $86,11 \%$ pada post test atau meningkat sebesar $75,00 \%$ sehingga hipotesis tindakan dalam penelitian ini diterima.
\end{abstract}

Kata kunci: Hasil Belajar Akuntansi, Model Pembelajaran Kooperatif Tipe Team Accelerated Instruction.

\begin{abstract}
This study aims to improve student's Accounting Learning Outcome of class XI Accounting 4 SMK N 1 Jogonalan academic year of 2016/2017 with implementation Cooperative Learning Method Type Team Accelerated Instruction (TAI). The data collection techniques used in this research were test and documentation. The including instrument used in this research are test and field note. The data analysis technique in this research was quantitative descriptive data analysis. Based on the research result, on the cycle I, the average score of accounting learning outcome in the pretest was 44,33 while in the post test, the average score was 82,11 or increased 37,78 or $85,22 \%$. On the cycle II, the average score of accounting learning outcome in the pretest was 48,89, while the post test, the average score was 91,11 or increased 42,22 or $86,36 \%$. On the cycle I, the student's accounting learning outcome completeness increased from 5,56\% on the pretest to 63,89\% on the posttest or increased 58,33\%. On the cycle II, the student's accounting learning outcome completeness increased from $11,11 \%$ of pretest to $86,11 \%$ on the posttest or increased $75,00 \%$ based on the result, hypothesis of action on this research is accepted.
\end{abstract}

Keywords: Accounting Learning Outcome, Cooperative Learning Method Team Accelerated Instruction. 


\section{PENDAHULUAN}

Pendidikan mempunyai peranan penting dalam meningkatkan kualitas sumber daya manusia. Untuk meningkatkan kualitas sumber daya manusia diperlukan adanya upaya peningkatan kualitas pendidikan. Upaya dalam peningkatan kualitas pendidikan tidak terlepas dari komponen-komponen yang mempengaruhi keberhasilan pembelajaran.

Proses pembelajaran merupakan komponen yang mempengaruhi keberhasilan pembelajaran. Guru sebagai tenaga kependidikan yang bertugas untuk melaksanakan proses pembelajaran menjadi pusat dari kegiatan belajar mengajar. Selain sebagai pelaksana dalam proses pembelajaran, guru juga berperan dalam menilai proses dan hasil belajar peserta didik melalui kegiatan evaluasi. Secara umum, evaluasi dilakukan dengan tujuan untuk melihat sejauh mana kemampuan belajar para siswa telah tercapai dalam program pendidikan yang telah dilaksanakan (Oemar Hamalik, 2011: 211). Melalui kegiatan evaluasi ini keberhasilan pembelajaran dapat diukur.

Menurut Nana Sudjana (2014:3), hasil belajar merupakan perubahan tingkah laku dari peserta didik yang mencakup bidang kognitif, afektif, dan psikomotorik. Ketiga bidang tersebut merupakan objek penilaian hasil belajar. Diantara ketiga bidang tersebut, bidang kognitif yang paling banyak dinilai oleh para guru di sekolah karena berkaitan dengan kemampuan para siswa dalam menguasai isi bahan pengajaran (Nana Sudjana, 2014:23). Ranah kognitif sendiri berkenaan dengan hasil belajar intelektual yang terdiri dari enam aspek, yaitu pengetahuan atau ingatan, pemahaman, aplikasi atau penerapan, analisis, sintesis dan evaluasi.

Hasil belajar merupakan hasil dari suatu interaksi tindak mengajar dan tindak belajar yang dilakukan oleh guru dan peserta didik. Menurut Slameto (200: 54-72) terdapat beberapa faktor yang mempengaruhi hasil belajar, yaitu: faktor intern dan faktor ekstern. 1. Faktor intern merupakan faktor yang ada dalam diri individu yang sedang belajar, meliputi: a) Faktor jasmaniah (faktor kesehatan dan cacat tubuh), b) Faktor psikologis (inteligensi, perhatian, minat, bakat, motif, kematangan, kesiapan), c) Faktor kelelahan. 2. Faktor ekstern merupakan faktor yang ada di luar individu, meliputi: a) Faktor keluarga (cara orang tua mendidik, relasi antar anggota keluarga, suasana rumah, keadaan ekonomi keluarga, pengertian orang tua, latar belakang kebudayaan), b) Faktor sekolah, (metode mengajar, kurikulum, relasi guru dan siswa, relasi siswa dengan siswa, disiplin sekolah, alat pengajaran, waktu sekolah, keadaan gedung); c) Faktor masyarakat (kegiatan siswa dalam masyarakat, media massa, teman bergaul, bentuk kehidupan masyarakat). Faktorfaktor inilah yang mengakibatkan hasil belajar setiap siswa berbeda.

SMK N 1 Jogonalan merupakan sekolah berstandar nasional yang memiliki dua kompetensi program pendidikan, yaitu salah satunya adalah Program Bisnis Manajemen.

Program Bisnis Manajemen terdiri dari Program Keahlian Akuntansi, Program Keahlian Administrasi Perkantoran dan Program Keahlian Pemasaran. Pada Program Keahlian Akuntansi dibagi menjadi 4 kelas yaitu AK 1, AK 2, AK 3, dan AK 4.

Mata pelajaran Kompetensi Kejuruan Akuntansi merupakan salah satu mata pelajaran yang wajib ditempuh oleh siswa Sekolah Menengah Kejuruan (SMK) program keahlian akuntansi. Salah satu standar kompetensi pada mata pelajaran kejuruan akuntansi adalah mengelola kartu utang. Kartu utang merupakan mata pelajaran akuntansi yang memahami dan menghitung besarnya jumlah utang suatu perusahaan yang dipergunakan untuk mengetahui mutasi utang secara terperinci setiap kreditor. Oleh karena itu, dibutuhkan kecermatan dan ketelitian dalam mata pelajaran ini.

Berdasarkan hasil dokumentasi yang diperoleh dari guru mata pelajaran akuntansi SMK N 1 Jogonalan diketahui hasil belajar 
Vilia Putri Sukmayahya \& Diana Rahmawati

$23-31$

akuntansi ranah kognitif pada standar kompetensi mengelola kartu utang kompetensi dasar mendeskripsikan pengelolalan kartu utang kelas XI Akuntansi 4 SMK N 1 Jogonalan tahun ajaran 2016/2017 kurang optimal, dimana dari 36 orang siswa, 18 orang siswa $(50 \%)$ yang belum memenuhi Kriteria Ketuntasan Minimal (KKM). Berdasarkan wawancara dengan guru proses pembelajaran dikatakan berhasil apabila minimal $75 \%$ dari jumlah siswa dalam satu kelas mencapai KKM. Dalam segi hasil, pembelajaran dapat dikatakan berhasil dan berkualitas apabila terjadi perubahan perilaku yang positif dari diri siswa seluruhnya atau setidaknya sebagian besar (75\%) (Mulyasa, 2013:218). Jumlah persentase siswa yang belum mecapai KKM dikelas XI Akuntansi 4 SMK $\mathrm{N}$ Jogonalan masih $<75 \%$ maka hasil belajar kelas XI Akuntansi 4 SMK N 1 Jogonalan masih dapat dikatakan belum optimal.

Pada dasarnya siswa memiliki kemampuan dan tingkat pengetahuan yang berbeda-beda. Hasil belajar yang dicapai siswa juga berbeda-beda. Kurangnya peran siswa dalam pembelajaran yang terlihat dari minimnya kesempatan siswa untuk bekerjasama atau bertukar pikiran mengakibatkan hasil belajar akuntansi yang dicapai oleh siswa belum optimal. Dalam kegiatan pembelajaran terdapat beberapa faktor yang mempengaruhi, di antaranya faktor guru, faktor siswa, sarana, alat, dan media yang tersedia, serta faktor lingkungan (Wina Sanjaya, 2013: 52).

Faktor guru merupakan salah satu komponen yang mempengaruhi keberhasilan pembelajaran dalam hal ini metode mengajar yang digunakan. Berdasarkan observasi yang dilakukan, guru masih menyampaikan materi dengan menggunakan metode ceramah dan latihan. Begitu pula karakteristik siswa yang lebih suka bertanya dengan teman sebaya daripada guru. Selain itu, dalam proses pembelajaran guru masih berfokus pada penggunaan buku cetak dan pemanfatan LCD proyektor belum optimal. Hal ini dapat berpengaruh terhadap Hasil Belajar Akuntansi yang dicapai oleh siswa belum optimal. Guru diharapkan mampu menyajikan materi pelajaran dengan menggunakan metode yang lebih menarik yang dapat meningkatkan kerjasama antar siswa sehingga dapat meningkatkan hasil belajar akuntansi siswa. Salah satu alternatifnya adalah model pembelajaran kooperatif yang diharapkan dapat meningkatkan partisipasi siswa dalam pembelajaran. Adanya partisipasi dari siswa maka akan meningkatkan pemahaman tentang materi yang disampaikan.

Model Pembelajaran Kooperatif ini mendorong peserta didik aktif dalam belajar berkelompok sehingga dapat meningkatkan tingkat pemahaman siswa. Salah satu model pembelajaran kooperatif yang dapat diterapkan guru adalah tipe Team Accelerated Intruction (TAI) yang pada awalnya dikenal dengan Team Assisted Instruction. Menurut Slavin (2010: 187) dasar pemikiran Team Accelerated Intruction (TAI) adalah untuk mengadaptasi pengajaran terhadap perbedaan individual berkaitan dengan kemampuan siswa maupun pencapaian prestasi siswa. Dalam pembelajaran kooperatif tipe Team Accelerated Instruction (TAI), siswa dibagi dalam kelompok dimana setiap kelompok terdiri dari siswa yang mempunyai kemampuan lebih dan siswa yang mempunyai kemampuan rendah. Untuk menjamin heterogenitas keanggotaan kelompok, gurulah yang membentuk kelompok-kelompok tersebut.

Model pembelajaran kooperatif tipe TAI ini merupakan model pembelajaran yang menekankan pada peran aktif siswa. Dimana siswa dibentuk secara berkelompok secara heterogen. Siswa yang mempunyai kemampuan lebih tinggi berperan sebagai tutor yang bertugas membantu secara individual siswa lain dalam suatu kelompok yang mempunyai kemampuan rendah. Dalam hal ini peran guru hanya sebagai fasilitator dalam proses belajar mengajardapat digunakan untuk membantu siswa jika siswa mengalami kesulitan belajar secara individual dalam proses pembelajaran. Hal ini sesuai dengan 
karakteristik siswa yang lebih suka dan nyaman untuk bertanya kepada teman sebaya daripada kepada guru. Oleh karena itu Model Pembelajaran Kooperatif Tipe Team Accelerated Instruction ini lebih cocok diterapkan pada kelas XI Akuntansi 4 tahun ajaran 2016/2017 dibandingkan model pembelajaran kooperatif tipe lainnya.

Kelebihan dari Model Pembelajaran Kooperatif Tipe Team Accelerated Instruction (TAI) ini yaitu guru bisa lebih menfokuskan pembelajaran pada kelompokkelompok kecil sehingga siswa dapat menyerap materi lebih baik daripada dalam kelompok besar, selain itu, siswa juga dapat belajar secara individu melalui sistem pengecekan pekerjaan teman sekelompok sehingga siswa dapat memahami materi dengan mencari jawabannya sendiri. Pembelajaran tipe TAI akan memotivasi siswa untuk saling membantu anggota kelompoknya sehingga terciptanya semangat dalam proses pembelajaran yang pada akhirnya dapat berpengaruh positif terhadap hasil belajar akuntansi siswa.

Pembelajaran Team Accelerated Instruction (TAI) ini cocok diterapkan untuk materi akuntansi utang pada kompetensi dasar mengidentifikasi data utang karena pada metode TAI ini siswa dapat mengatasi kesulitan belajar yang dibantu oleh teman sebaya. Siswa yang mempunyai kemampuan lebih dapat membantu siswa yang mempunyai kemampuan rendah dalam mengatasi kesulitan belajar. Hal ini dikarenakan materi akuntansi utang berhubungan dengan kemampuan memahami dan menghitung sehingga membutuhkan kesungguhan, kecermatan, dan ketelitian. Tutor sebaya melalui model pembelajaran kooperatif tipe Team Accelerated Instruction (TAI) ini dapat membantu dalam meningkatkan hasil belajar akuntansi siswa dalam kompetensi dasar mengidentifikasi data utang.

Berdasarkan uraian singkat di atas peneliti tertarik melakukan penelitian dengan judul "Implementasi Model Pembelajaran Kooperatif Tipe Team Accelerated Instruction (TAI) untuk meningkatkan Hasil Belajar Akuntansi Siswa Kelas XI Akuntansi 4 SMK N 1 Jogonalan Tahun Ajaran 2016/2017”.

Tujuan penelitian ini adalah meningkatkan Hasil Belajar Akuntansi Siswa kelas XI Akuntansi 4 SMK N 1 Jogonalan tahun ajaran 2016/2017 melalui Implementasi Model Pembelajaran Kooperatif Tipe Team Accelerated Instruction (TAI). Hasil penelitian ini diharapkan dapat memberikan kontribusi bagi ilmu pengetahuan dan dapat digunakan untuk referensi dan bahan pertimbangan pada penelitian yang selanjutnya. Selain itu, diharapkan dapat meningkatkan Hasil Belajar Akuntansi siswa secara optimal melalui implementasi Model Pembelajaran Kooperatif Tipe Team Accelerated Instruction (TAI). Penelitian ini diharapkan dapat digunakan oleh guru dapat menggunakan model pembelajaran kooperatif tipe Team Accelerated Instruction (TAI) sebagai salah satu pilihan model dalam pembelajaran akuntansi untuk meningkatkan Hasil Belajar Akuntansi siswa.

\section{METODE PENELITIAN Jenis Penelitian}

Jenis penelitian ini adalah Penelitian Tindakan Kelas (PTK) dalam bentuk kolaboratif dengan guru mata pelajaran akuntansi kelas XI Akuntansi 4 SMK N 1 Jogonalan tahun ajaran 2016/2017. Penelitian Tindakan Kelas dilakukan dalam 2 siklus namun dilanjutkan ke siklus berikutnya apabila belum mencapai indikator keberhasilan yang telah ditentukan (Suharsimi Arikunto, 2016:42). Dalam Penelitian Tindakan Kelas terdapat empat tahapan yang lazim dilakukan, yaitu (1) perencanaan, (2) pelaksanaan, pengamatan, dan (4) refleksi.

\section{Waktu dan Tempat Penelitian}

Kelas XI Akuntansi 4 SMK Negeri 1 Jogonalan yang beralamat di Jalan YogyaSolo, Kelurahan Prawatan, Kecamatan Jogonalan, Jawa Tengah. penelitian ini dilaksanakan pada bulan Maret - April 
Tahun Ajaran 2016/2017 terhitung sejak pelaksanaan penelitan hingga penyusunan laporan penelitian.

\section{Subjek dan Objek Penelitian}

Subjek dalam penelitian ini adalah siswa Kelas XI Akuntansi 4 SMK N 1 Jogonalan Tahun Ajaran 2016/2017 sebanyak 36 siswa dan objek penelitian adalah Hasil Belajar Akuntansi Siswa Kelas X1 Akuntansi 4 SMK N 1 Jogonalan pada Tahun Ajaran 2016/2017.

\section{Prosedur Penelitian}

Penelitian ini merupakan Penelitian Tindakan Kelas (PTK) yang dilakukan dalam empat tahap, yaitu perencanaan, pelaksanaan, observasi, dan refleksi. Penelitian ini menerapkan Model Pembelajaran Kooperatif Tipe Team Accelerated Instruction (TAI) yang dilaksanakan sebanyak dua siklus. Berikut adalah prosedur penelitian yang dilakukan:

a. Siklus I

1) Tahap Perencanaan

Pada tahap ini, peneliti menyiapkan berbagai hal yang digunakan dalam penelitian yaitu menyusun Rencana Pelaksanaan Pembelajaran (RPP) dengan materi utang obligasi, membuat jadwal pelaksanaan kegiatan pembelajaran, mempersiapkan materi pembelajaran yang digunakan, menyusun soal pre test dan post test, menyiapkan catatan lapangan untuk mencatat kegiatan atau proses pembelajaran, membagi siswa dalam 8 kelompok secara heterogen, menyusun soal diskusi, mengkonsultasikan dengan guru terkait persiapan proses pembelajaran dengan mengimplementasikan Model Pembelajaran kooperatif Team Accelerated Instruction (TAI)

2) Tahap Pelaksanaan

Tahap pelaksanaan merupakan tahap untuk mengimplementasikan dari perencanaan yaitu kegiatan guru melaksanakan proses atau kegiatan pembelajaran dengan menerapkan Model Pembelajaran Kooperatif Tipe Team Accelerated Instruction (TAI). Tahap pelaksanaan yang dilakukan di dalam kelas disesuaikan dengan RPP yang telah dibuat. Adapun tahap pelaksanaannya meliputi kegiatan pendahuluan, kegiatan inti, dan kegiatan penutup.

3) Tahap Pengamatan

Tahap pengamatan ini dilakukan saat proses pembelajaran berlangsung melalui pengukuran. Pengamatan ini digunakan untuk mengamati pengimplementasian model Team Accelerated Instruction yang di lakukan oleh guru pada saat proses pembelajaran berlangsung dan Hasil Belajar Akuntansi siswa.

4) Tahap Refleksi

Tahap refleksi dilakukan segera setelah proses pembelajaran selesai dengan diskusi antara guru model dan peneliti untuk membahas pembelajaran yang telah dilakukan. Hasil dari diskusi yang dilakukan digunakan sebagai pertimbangan dalam merencanakan pembelajaran selanjutnya.

b. Siklus II

1) Tahap Perencanaan

Tahap perencanaan pada siklus II ini secara garis besar hampir sama dengan siklus I. Hanya saja pada perencanaan siklus II ini terdapat beberapa perbaikan yang diperlukan berdasarkan hasil penelitian pada siklus I. Pembuatan RPP, pre test, dan post test sesuai dengan materi lanjutan siklus I yaitu utang hipotik.

2) Tahap Pelaksanaan

Tahap pelaksanaan sama dengan pelaksanaan kegiatan pada siklus I. Guru model melaksanakan desain pembelajaran sesuai RPP. Materi pokok yang disampaikan yaitu utang hipotik.

3) Tahap Pengamatan 
Tahap pengamatan pada siklus II sama dengan tahap pengamatan pada siklus I. Pengamatan dilakukan selama kegiatan untuk mengamati proses pembelajaran dengan mengimplementasikan model pembelajaran Team Accelerated Instruction (TAI) untuk meningkatkan Hasil Belajar Akuntansi.

4) Tahap Refleksi

Tahap refleksi pada siklus II dilakukan segera setelah proses pembelajaran selesai dengan diskusi antara guru model dan peneliti untuk membahas pembelajaran yang telah dilakukan. Selain itu, tahap refleksi juga dilakukan untuk mengetahui peningkatan hasil belajar siswa dari kegiatan pembelajaran yang dilakukan pada siklus I dan II. Hal ini berguna untuk menentukan langkah selanjutnya yaitu keputusan akan menambah siklus atau tidak.

\section{Data, Instrumen, dan Teknik Pengumpulan}

a. Teknik Pengumpulan Data

Teknik pengumpulan data menggunakan tes, dan dokumentasi. Tes digunakan untuk mengetahui Hasil Belajar Akuntansi siswa pada ranah kognitif yang meliputi pengetahuan (C1), pemahaman (C2), dan penerapan (C3). Dokumentasi dalam penelitian ini digunakan untuk memperoleh data siswa dan data hasil belajar siswa sebagai data awal penelitian.

b. Instrumen Penelitian

Instrumen penelitian yang digunakan yaitu tes dan catatan lapangan. Tes yang diberikan berbentuk objektif dan uraian. Tes diberikan pada awal dan akhir pembelajaran berupa pre test dan post test untuk mengetahui peningkatan hasil belajar siswa. Catatan lapangan digunakan untuk mencatat segala hal yang terjadi berkaitan dengan berlangsung proses pembelajaran. c. Teknik Analisis Data

1) Analisis Data Deskriptif Kuantitatif'

a) Analisis Kualitas Tes

Analisis kualitas tes ini dapat dilihat dari validitas, reliabilitas, tingkat kesukaran, daya pembeda, dan pola jawaban soal. Dalam penelitian ini, analisis dilakukan dengan menggunakan software Anates V4.

b) Menghitung Peningkatan Hasil Belajar Akuntansi

Menghitung peningkatan nilai rata-rata pre test dan post test pada siklus I dan II, dengan rumus sebagai berikut:

$M e=\frac{\sum x i}{N}$

(Sugiyono,

2010: 49)

Peningkatan Hasil Belajar Akuntansi dapat dilihat dengan menghitung ketuntasan belajar menggunakan rumus sebagai berikut:

$$
\mathrm{KB}=\frac{T}{T_{t}} \times 100 \%
$$

(Trianto, 2012: 241)

2) Penyajian Data

Data yang telah diolah kemudian disajikan ke dalam bentuk tabel dan grafik. Dari tabel dan grafik tersebut, data akan dipaparkan secara naratif agar lebih mudah dipahami.

3) Penarikan Kesimpulan

Penarikan kesimpulan merupakan tahap terakhir dalam analisis data. Setelah data disajikan, dari data tersebut akan diambil intisari yang dituliskan dalam bentuk pernyataan yang memiliki makna lebih tegas atas hasil analisis yang telah dilakukan.

\section{HASIL PENELITIAN PEMBAHASAN}

Penelitian yang telah dilakukan membuktikan bahwa implementasi model pembelajaran Kooperatif Tipe Team Accelerated Instruction (TAI) dapat meningkatkan Hasil Belajar Akuntansi. 
Hasil belajar kognitif Standar Kompotensi Mengelola Kartu Utang diukur melalui pre test dan post test dengan Kompetensi Dasar Mengidentifikasi Data Utang.

Materi yang digunakan pada siklus I adalah Utang Obligasi sedangkan pada siklus II yaitu Utang Hipotik. Berdasarkan pelaksanaan pembelajaran menggunakan Model Pembelajaran Kooperatif Tipe Team Accelerated Instruction (TAI) pada siklus I dan siklus II menunjukkan adanya peningkatan hasil belajar siswa dalam ranah kognitif.

Tabel peningkatan nilai rata-rata Hasil Belajar Akuntansi siswa kelas XI Akuntansi 4 SMK N 1 Jogonalan tahunajaran 2016/2017 pada siklus I dan siklus II dapat dilihat pada tabel 1 .

Tabel 1. Peningkatan Rata-rata Hasil Belajar Akuntansi pada Siklus I dan Siklus II

\begin{tabular}{|l|l|l|r|r|}
\hline \multirow{2}{*}{ Siklus } & \multicolumn{2}{|c|}{$\begin{array}{l}\text { Nilai Rata- } \\
\text { rata Kelas }\end{array}$} & \multicolumn{2}{c|}{ Peningkatan } \\
\cline { 2 - 5 } & $\begin{array}{l}\text { Pre } \\
\text { Test }\end{array}$ & $\begin{array}{l}\text { Post } \\
\text { Test }\end{array}$ & Absolut & Relatif \\
\hline I & 44,33 & 82,11 & 37,78 & $85,22 \%$ \\
\hline II & 48,89 & 91,11 & 42,22 & $86,36 \%$ \\
\hline
\end{tabular}

Sumber: Data primer yang diolah

Peningkatan Hasil Belajar Akuntansi tersebut juga dapat dilihat pada diagram dibawah ini:

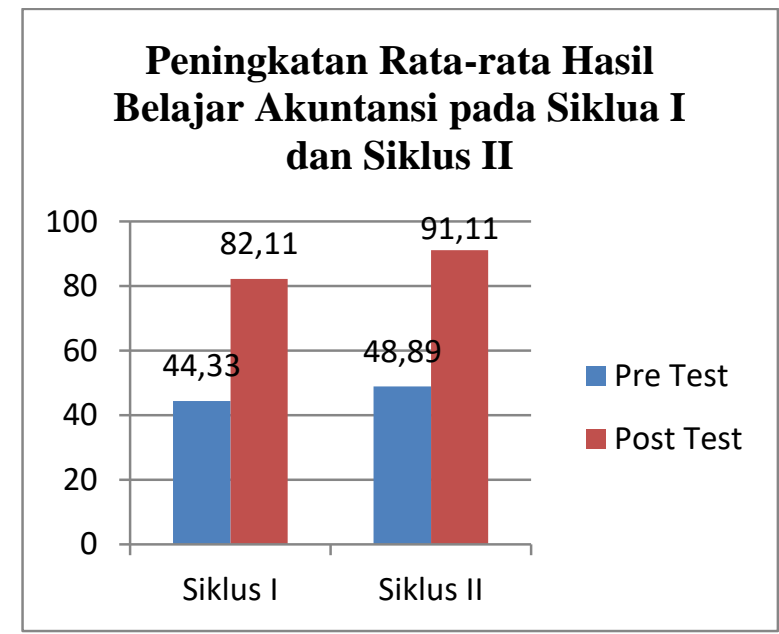

Gambar 1. Peningkatan Nilai Rata-rata Hasil Belajar Akuntansi
Berdasarkan tabel dan diagram tersebut, diketahui bahwa telah terjadi peningkatan rata-rata Hasil Belajar Akuntansi pada siklus I dan siklus II setelah adanya Implementasi Model Pembelajaran Kooperatif Tipe Team Accelerated Instruction (TAI).

Rata-rata Hasil Belajar Akuntansi pada pre test siklus I sebesar 44,33 meningkat menjadi sebesar 82,11 pada post test atau meningkat sebesar 37,78 atau $85,22 \%$. Pada siklus II nilai rata-rata Hasil Belajar Akuntansi pada pre test sebesar 48,89 meningkat menjadi sebesar 91,11 pada post test atau meningkat sebesar 42,22 atau $86,36 \%$. Data tersebut membuktikan bahwa implementasi Model Pembelajaran Kooperatif Tipe Team Accelerated Instruction (TAI) dapat meningkatkan Hasil Belajar Akuntansi.

Peningkatan Hasil Belajar Akuntansi juga dapat dilihat dari peningkatan ketuntasan Hasil Belajar Akuntansi pada siklus I dan siklus II. Berikut ini tabel ketuntasan Hasil Belajar Akuntansi pada siklus I dan siklus II.

Tabel 2. Peningkatan Ketuntasan Hasil Belajar Akuntansi pada Siklus I dan Siklus II

\begin{tabular}{|c|l|c|l|}
\hline Siklus & \multicolumn{2}{|c|}{$\begin{array}{c}\text { Ketuntasan Hasil } \\
\text { Belajar Akuntansi }\end{array}$} & $\begin{array}{l}\text { Pening- } \\
\text { katan }\end{array}$ \\
\cline { 2 - 3 } & Pre Test & $\begin{array}{c}\text { Post } \\
\text { Test }\end{array}$ & \multirow{2}{*}{} \\
\cline { 2 - 3 } & $\mathbf{N} \geq \mathbf{7 8}$ & $\mathbf{N} \leq \mathbf{7 8}$ & \\
\hline I & $5,56 \%$ & $63,89 \%$ & $58,33 \%$ \\
\hline II & $11,11 \%$ & $86,11 \%$ & $75,00 \%$ \\
\hline
\end{tabular}

Sumber: Data primer yang diolah Keterangan: $\mathrm{N}=$ Nilai

Peningkatan Ketuntasan Hasil Belajar Akuntansi Siklus I dan Siklus II ini juga disajikan dalam diagram berikut ini: 


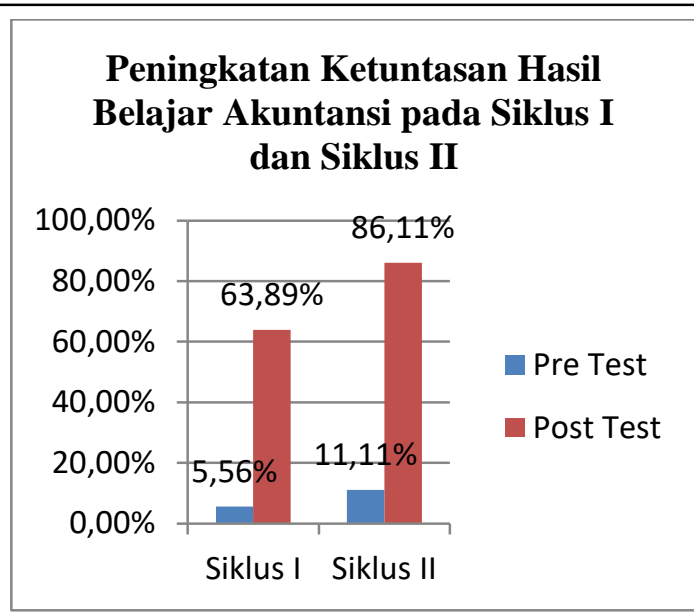

\section{Gambar 2. Peningkatan Ketuntasan Belajar Siswa pada Siklus I dan Siklus II}

Berdasarkan tabel dan diagram tersebut dapat diketahui bahwa telah terjadi peningkatan ketuntasan Hasil Belajar Akuntansi setelah adanya implementasi Model Pembelajaran Kooperatif Tipe Team Accelerated Instruction (TAI). Ketuntasan Hasil Belajar Akuntansi pada pre test siklus I sebesar 5,56\% meningkat menjadi $63,89 \%$ pada post test atau meningkat sebesar 58,33\%. Pada siklus II, ketuntasan Hasil Belajar Akuntansi pada pre test sebesar $11,11 \%$ meningkat menjadi $86,11 \%$ pada post test atau meningkat sebesar $75 \%$. Jika ketuntasan Hasil Belajar Akuntansi pada siklus I dan siklus II dibandingkan, maka peningkatan ketuntasan Hasil Belajar Akuntansi pada siklus II lebih besar daripada peningkatan yang terjadi pada siklus I. Selain itu, ketuntasan Hasil Belajar Akuntansi pada siklus II juga telah memenuhi indikator keberhasilan belajar karena $86,11 \%$ siswa dalam satu kelas telah mencapai nilai Kriteria Ketuntasan Minimal (KKM) yang telah ditetapkan oleh sekolah.

Jika kedua siklus dibandingkan, maka peningkatan ketuntasan Hasil Belajar Akuntansi pada siklus II lebih besar daripada peningkatan ketuntasan Hasil Belajar Akuntansi pada siklus I. Berdasarkan analisis data diketahui peningkatan dari post test siklus I ke post test siklus II adalah sebesar 27,78\%. Indikator keberhasilan Hasil Belajar
Akuntansi siswa kelas XI Akuntansi 4 SMK N 1 Jogonalan telah tercapai di akhir siklus II yaitu lebih dari $75 \%$ siswa telah mencapai nilai KKM yaitu sebesar $86,11 \%$. Hal tersebut sesuai dengan Nana Sudjana (2009: 8) yang menyatakan bahwa siswa dikatakan berhasil apabila siswa menguasai atau dapat mencapai sekitar $75 \%$ atau lebih dari tujuan atau nilai yang seharusnya dicapai.

Data tersebut telah membuktikan bahwa implementasi Model Pembelajaran Kooperatif Tipe Team Accelerated Instruction (TAI) dapat meningkatkan Hasil Belajar Akuntansi. Dengan demikian, hipotesis tindakan dalam penelitian ini dinyatakan diterima.

\section{SIMPULAN DAN SARAN \\ Simpulan}

Berdasarkan hasil penelitian dan pembahasan, maka dapat disimpulkan bahwa Implementasi Model Pembelajaran Kooperatif Tipe Team Accelerated Instruction (TAI) dapat meningkatkan Hasil Belajar Akuntansi siswa kelas XI Akuntansi 4 SMK N 1 Jogonalan tahun ajaran 2016/2017. Hal ini dibuktikan dengan peningkatan nilai rata-rata Hasil Belajar Akuntansi dan peningkatan ketuntasan Hasil Belajar Akuntansi dari siklus I ke siklus II. Rata-rata Hasil Belajar Akuntansi pada pre test siklus I sebesar 44,33 meningkat menjadi sebesar 82,11 pada post test atau meningkat sebesar 37,78 atau $85,22 \%$. Pada siklus II, rata-rata Hasil Belajar Akuntansi pada pre test sebesar 48,89 meningkat menjadi sebesar 91,11 pada post test atau meningkat sebesar 42,22 atau 86,36\%. Ketuntasan Hasil Belajar Akuntansi pada pre test siklus I sebesar 5,56\% meningkat menjadi sebesar $63,89 \%$ pada post test atau meningkat sebesar 58,33\%. Pada siklus II, ketuntasan Hasil Belajar Akuntansi pada pre test sebesar $11,11 \%$ meningkat menjadi $86,11 \%$ pada post test atau meningkat sebesar $75 \%$. 
Saran

a. Bagi Guru

1) Model Pembelajaran Kooperatif Tipe Team Accelerated Instruction sebaiknya lebih sering digunakan dalam proses pembelajaran di kelas termasuk digunakan pada materi pokok yang lain karena strategi ini terbukti mampu meningkatkan Hasil Belajar Akuntansi siswa.

2) Guru sebaiknya memberikan soalsoal latihan tambahan kepada siswa yang mendapatkan nilai di bawah Kriteria Ketuntasan Minimal (KKM), agar siswa dapat menguasai materi yang telah diajarkan.

3) Guru sebaiknya melakukan uji kualitas tes terlebih dahulu sebelum tes diberikan kepada siswa sehingga tes yang diberikan benar-benar berkualitas dari segi validitas, reliabilitas, tingkat kesukaran, daya pembeda, dan pola jawaban soal.

b. Bagi Peneliti Lain

Bagi peneliti selanjutnya, sebaiknya waktu yang digunakan dalam melakukan penelitian tidak singkat yaitu dengan menambah jumlah pertemuan sehingga dapat menggambarkan bagaimana kondisi sesungguhnya dan pencapaian Hasil Belajar Akuntansi siswa akan lebih maksimal.

\section{DAFTAR PUSTAKA}

Mulyasa. (2013). Implementasi Kurikulum Tingkat Satuan Pendidikan Kemandirian Guru dan Kepala Sekolah. Jakarta: Bumi Aksara

Nana Sudjana. (2014). Penilaian Hasil Proses Belajar Mengajar. Bandung: PT Rosdakarya.

Oemar Hamalik. (2011). Perencanaan Pengajaran Berdasarkan Pendekatan Sistem. Jakarta: Bumi Aksara

Slameto. (2010). Belajar dan Faktor-faktor yang Mempengaruhinya. Jakarta: Rineka Cipta.
Slavin, Robert E. (2010). Cooperative Learning. Bandung: Nusa Media.

Sugiyono. (2010). Metode Penelitian Pendidikan. Bandung: Alfabeta.

Suharsimi Arikunto. (2016). Penelitian Tindakan Kelas. Jakarta: PT Bumi Aksara.

Trianto. (2012). Mendesain Model Pembelajaran Inovatif-Progresif: Konsep, Landasan, dan Implementasinya pada Kurikulum Tingkat Satuan Pendidikan (KTSP). Jakarta: Kencana.

Wina Sanjaya. (2013). Strategi Pembelajaran Berorientasi Standar Proses Pendidikan. Jakarta: Kencana Prenada Media. 